\title{
Călin-Ioan Dușe, Imperiul Roman și creștinismul în timpul Părinților Apostolici, Cluj-Napoca, Presa Universitară Clujeană, 2019, 475 p.
}

Lucrarea Părintelui Călin-Ioan Dușe, Imperiul Roman și creștinismul în timpul Părinților Apostolici, tratează cele mai importante aspecte ale statului roman din - perioada republicană şi imperială, cu referire specială la perioada secolului I d.Hr, secol în care au activat Părinții

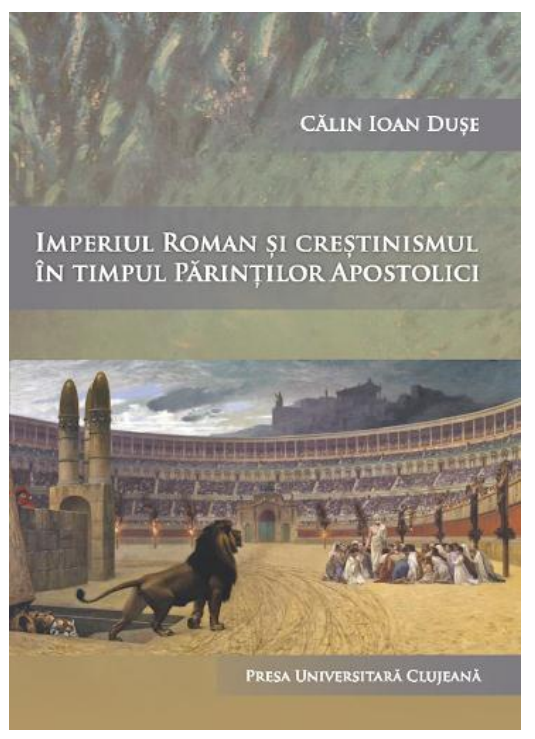
Apostolici. Lucrarea propusă este o remarcabilă reconstituire a contextului lumesc, în care sa întrupat Fiul lui Dumnezeu, și a modului în care taina persoanei și a lucrării Sale mântuitoare a fost receptată şi aprofundată în perioada Părinților Apostolici.

Structurată în cinci capitole, fiecare capitolavând bibliografie proprie, lucrarea dorește să prezinte evoluția Imperiului Roman de la început şi în ce context își face apariţia noua religie-creștinismul. Totodată ajunge să descrie 
mentalităţile romanilor, cultura, filosofia și religia romană în momentul apariţiei creștinismului.

Capitolul I, intitulat Scurtă istorie Imperiului Roman, tratează perioada etruscăa Romei, perioada Regalității, a Republicii, a Imperiului, cu referire specială la principalii împărați romani din secolul I. Aici autorul întreprinde o scurtă incursiune în istoria Imperiului Roman şi tratează modul în care etruscii şi-au pus amprenta asupra evoluției acestuia.

Capitolul al II-lea, purtând titlul Instituțiile romane, se referă la marile instituții ale statului roman, fiind amintite: armata, instituțiile sociale, cele juridice, economia, demografia, construcțiile și arhitectura. Autorul afirmă și susține cu argumente pertinente că romanii au fost un popor practic și, astfel, dreptul roman a evoluat pe parcursul secolelor concomitent cu viaţa socială, economică și politică.

Capitolul al III-lea poartă ca titlu o sinteză a vremii privind Cultura, Filosofia și religia romană, și prezintă educația în statul roman, marile personalități culturale ale epocii, filosofia și sistemul religios greco-roman. În acest capitol, autorul trece dincolo de scrisul istoric intrând în programul cotidian al unui elev preocupat de educația sa. Aceasta scurtă incursiune este demnă de luat ca exemplu deoarece dezvăluie generațiilor de astăzi modul în care unul din cele mai mari imperii ale istoriei umane își pregătea tinerii. În acest sens, autorul oferă libertate de exprimare scriitorului antic Marcus Fabius Quintilian prin vocea căruia putem face cunoștință cu nivelul, modul și expectanțele educaţionale pentru fiecare nivel de școlarizare.

Capitolul al IV-lea, intitulat Apariția și răspândirea creștinismului, analizează starea lumii iudaice și greco-romane la începutul secolului I, activitatea Sfântului Ioan Botezătorul şi a Mântuitorului Iisus Hristos, precum și întemeierea Bisericii şi activitatea misionară a Apostolilor.

Ultimul capitol prezintă activitatea, viaţa, scrierile și teologia Părinților Apostolici din secolul I, cu aplecare specială către Sfântul Clement Romanul, Sfântul Ignatie Teoforul și Sfântul Policarp al Smirnei. 
Recenzie: Călin-Ioan Dușe, Imperiul Roman și creștinismul în timpul Părinților Apostolici

Lucrarea de față este însoțită de numeroase hărți și ilustrații, care ajută la vizualizarea elementelor descrise în carte, fapt ce o transformă într-un autentic manual și ghid pentru pasionații de istoria Imperiului Roman sau de modul în care creștinismul s-a răspândit și rolul avut de Părinții Apostolici în tot acest context. $\mathrm{Cu}$ o bibliografie foarte bogată, lucrarea de față este și un veritabil instrument de cercetare pentru cei care doresc să aprofundeze unul din subiectele majore pe care autorul le-a propuspentru analiză și discuție.

Elementul de noutate îl constituie abordarea istoriei Imperiului Roman pe înțelesul unui cititor care vrea să descopere mai mult despre instituţiile şi perioada Statului roman. De asemenea, lucrarea prezintă perioada și teologia Părinților Apostolici într-o lumină modernă, în acord cu abordarea teologilor contemporani.

Ținând cont de contribuțiile aduse domeniului cercetării, de firul logic și analitic al abordării, recomand călduros cartea Imperiul Roman și creștinismul în timpul Părinților Apostolici, a autorului, pentru a fi lecturată.

Pr. prof. univ. dr. Marius T,EPELEA

Facultatea de Teologie Ortodoxă „Episcop Dr. Vasile Coman” Universitatea din Oradea 